Tsaqofiya : Jurnal Pendidikan Bahasa dan Sastra Arab

Vol. 3 No. 2 Juli 2021, 148-157

P-ISSN : 2685-7022, E-ISSN : 2685-7103

DOI: https://doi.org/10.21154/tsaqofiya.v3i2.73

\title{
ANALISIS PEMBELAJARAN KOMUNIKASI ARAB DALAM PEMBELAJARAN BAHASA ARAB DI SMA AISYIYAH BOARDING SCHOOL BANDUNG
}

\author{
Selpi Oktaviani1, Maman Abdurrahman² \\ Universitas Pendidikan Indonesia \\ 1500223@Upi.edu
}

\section{Abstract}

This research is motivated by the difficulties experienced by students when learning Arabic communication takes place. Therefore, this study aims to describe Arabic communication learning, starting from planning, processing, evaluation and the obstacles that students feel when learning Arabic communication activities. This research uses a qualitative approach with descriptive methods. The sample in this study were students of class $X$ Social and teachers who taught Arabic communication. Data collection techniques used were observation, interviews, documentation and student questionnaires. To analyze the data, researchers used qualitative data analysis with data verification steps, data presentation and data reduction. The results showed that 1) Arabic communication learning planning by the teacher was well prepared, the teacher used the 2013 curriculum and Arabic communication modules that were compiled by themselves 2) The Arabic communication learning process went well and according to the procedure but there were some students who were slow to understand the material provided by the teacher 3) Evaluation of Arabic Communication learning including daily exams, midterm and final semester exams including oral tests, written tests and group assignments. 4) The obstacles experienced by students in learning Arabic communication, namely; the lack of student interest in learning Arabic, the lack of self-confidence when communicating using Arabic, the difference in the student's school background that makes students' Arabic language skills diverse.

Keywords: Learning, Speaking, Communication

\section{Abstrak}

Penelitian ini dilatar belakangi oleh adanya kesulitan yang dirasakan siswa ketika pembelajaran komunikasi Arab berlangsung. Oleh karena itu, penelitian ini bertujuan untuk mendeskripsikan pembelajaraan komunikasi Arab, mulai dari perencanaan, proses, evaluasi serta kendala yang dirasakan siswa ketika kegiatan pembelajaran komunikasi Arab.Penelitian ini menggunakan pendekatan kualitatif dengan metode deskriptif. Sampel pada penelitian ini adalah siswa kelas X IPS dan Guru yang mengajar komunikasi Arab. Teknik pengumpulan data yang digunakan adalah observasi, wawancara, dokumentasi dan kuisioner siswa. Untuk menganalisis data peneliti menggunakan analisis data kualitatif dengan langkahlangkah verifikasi data, penyajian data dan reduksi data. Hasil penelitian menunjukkan bahwa 1) Perencanaan pembelajaran komunikasi Arab oleh pengajar dipersiapkan dengan baik, guru memakai kurikulum 2013 dan modul komunikasi Arab yang disusun sendiri 2) Proses pembelajaran komunikasi Arab 
berjalan dengan baik dan sesuai prosedur namun ada bebrapa siswa yang lamban memahami materi yang diberikan guru, 3) Evaluasi pembelajaran Komunikasi Arab diantaranya adalah ujian harian, ujian tengah semester dan ujian akhir semester meliputi test lisan, test tulis dan tugas berkelompok. 4) Kendala yang dialami siswa dalam pembelajaran komunikasi Arab yaitu; kurangya minat siswa dalam mempelajari bahasa Arab, kurangnya rasa percaya diri siswa ketika berkomunikasi menggunakan bahasa Arab, perbedaan latar belakang sekolah siswa yang menjadikan kemampuan berbahasa Arab siswa beragam.

Kata Kunci:Pembelajaran, Maharah Kalam, Komunikasi

\section{Pendahuluan}

Salah satu keterampilan berbahasa yang penting untuk dipelajari dan dikuasai adalah berbicara. Berbicara adalah aktivitas berbahasa kedua yang dilakukan manusia dalam kehidupan berbahasa setelah mendengarkan.Kenyataan dalam kehidupan sehari-hari membuktikan bahwa penguasaan bahasa lisan lebih banyak dibutuhkan daripada keterampilan berbahasa lainnya. Oleh karena itu, kemampuan berbicara seharusnya mendapat perhatian yang cukup dalam pembelajaran bahasa. ${ }^{1}$

Adapun dalam tujuan utama pembelajaran bahasa asing adalah pengembangan kemampuan pelajar dalam menggunakan bahasa itu baik lisan maupun tulis. Kemampuan menggunakan bahasa dalam dunia pengajaran bahasa disebut keterampilan berbahasa (maharah al-lughah). Keterampilan tersebut ada empat, yaitu keterampilan menyimak (maharah al-istima"/listening skills), berbicara (maharah al-kalam/speaking skill), membaca (maharah al-qiraah/reading skill), dan menulis (maharah al-kitabah/writing skill). ${ }^{2}$

Sementara itu, tujuan mempelajari bahasa Arab di sekolah adalah untuk mengembangkan kemampuan berbahasa asing secara lisan maupun tertulis.Peserta didik pun harus menguasai sejumlah kompetensi yang diharapkan dengan tujuan untuk mewujudkan masyarakat belajar. Sehingga siswa memiliki sejumlah kemampuan berbahasa yang dapat digunakan dan dikuasai. ${ }^{3}$

\footnotetext{
${ }^{1}$ Ahmad Muhtadi Anshor, Pengajaran Bahasa Arab Media Dan Metode-Metodenya (Yogyakarta: Teras, 2009).

${ }^{2}$ Bisri Mustofa and M Abdul Hamid, Metode Dan Strategi Pembelajaran Bahasa Arab (UINMaliki Press, 2016).

${ }^{3}$ Siti Sholihah and M Nasrullah, “Al-'Alaaqat Bayna Al-Dzaka'I Al-Ma'rifiyy Wa Nataaij Dars AlLughat Al-'Arabiyyat Li Thullaab Al-Shaff Al-'Asyir Bi Al-Madrasat Al-'Aliyat Al-Islaamjiyyat AlHukuumiyyat Al-Tsaaniyyat,” Tsaqofiya: Jurnal Pendidikan Bahasa Dan Sastra Arab 1, no. 1 (2019): 3654.
} 
Pada awalnya, seseorang mempelajari bahasa Arab hanya untuk memahami teks-teks keagamaan. Akan tetapi pada era modern ini, mempelajari bahasa Arab lebih difokuskan pada tujuan komunikasi. ${ }^{4}$ Pembelajar tidak cukup mampu berbahasa secara pasif, namun juga harus mampu berbahasa secara aktif. Bentuk konkretnya adalah dengan cara berkomunikasi dengan guru ketika di kelas, bersama teman maupun penutur asli. 5

Oleh karena itu, untuk mendukung suatu pembelajaran yang diharapkan dapat meningkatkan kemampuan siswa dalam berbicara bahasa Arab, terdapat beberapa faktor termasuk guru yang mengajar kepada siswa. Sehubungan dengan hal tersebut, SMA Islam sebagai institusi dalam sekolah Islam tentu mempunyai peran penting dalam mencetak calon intelektual muslim yang mampu menguasai berbagai bidang ilmu pengetahuan Islam maupun kemampuan berbahasa terutama bahasa Arab.

SMA Aisyiyah Boarding School merupakan Sekolah Menengah Atas yang menetapkan kurikulum bahasa Arab sebagai mata pelajaran yang wajib diikuti oleh peserta didik kelas $\mathrm{X}$, siswa diharapkan mampu menguasai keterampilan berbahasa Arab sesuai dengan kurikulum 2013 diantaranya ialah keterampilan berbicara. SMA Aisyiyah Boarding school Bandung menyediakan mata pelajaran khusus bagi keterampilan berbicara, yaitu mata pelajaran Komunikasi Arab.

Walaupun demikian, dalam pembelajaran komunikasi Arab masih ditemukan berbagai kendala yang dirasakan oleh guru maupun siswa. Sehingga dampaknya pencapaian tujuan pembelajaran manjadi tidak optimal. Berdasarkan pra penelitian yang dilakukan peneliti di SMA Aisyiyah Boarding School Bandung, kendala yang dirasakan oleh guru dan siswa dalam proses pembelajaran komunikasi Arab ini ialah: 1) kurangnya minat siswa dalam berkomunikasi menggunakan bahasa Arab dan 2) perbedaan latar belakang siswa dalam pemahaman bahasa Arab.

Berdasarkan permasalahan yang ditemukan, peneliti bertujuan untuk mengidentifikasi bagaimana perencanaan, proses, evaluasi dan kendala apa saja yang terdapat dalam pembelajaran komunikasi Arab siswa kelas X di SMA Aisyiyah

\footnotetext{
4 Abdul Wahab Rosyidi and Mamlu'atul Ni'mah, Memahami Konsep Dasar Pembelajaran Bahasa Arab (UIN-Maliki Press, 2011).

${ }^{5}$ Muhammad Nur Kholis et al., “Google Form Ka Wasīlah At-Taqyīm FīTa'līm Al-Qirāah Wa AlQawā'id Bi Al-Jāmi'ah,” LISANIA: Journal of Arabic Education and Literature 4, no. 1 (2020): 80-107.
} 
Boarding School Bandung, hal ini menjadi faktor pendorong penulis untuk memilih tema ini.

\section{METODE}

Metode yang digunakan dalam penelitian ini adalah metode analisis deskriptif. Pemilihan metode ini bertujuan untuk menggambarkan, menggungkapkan, dan menjelaskan langkah-langkah pembelajaran komunikasi dalam Pembelajaran Bahasa Arab Di SMA Aisyiyah Boarding School Bandung. Penelitian ini menggunakan pendekatan kualitatif melalui studi kasus di mana dalam penelitian ini tidak memaparkan angka-angka perhitungan, tetapi menampilkan analisis data yang diperoleh pada penelitian lapangan. Penulis menggunakan pendekatan ini karena lebih sesuai dengan objek yang akan diteliti

Penelitian ini dilakukan di di SMA Aisyiyah Boarding School Bandung yang beralamat di Jalan Terusan Rancagoong II, Gumuruh, Bandung, Jawa Barat. Subjek dalam penelitian ini adalah siswi kelas X SMA Aisyiyah Boarding School Bandung. Sedangkan informan yaitu guru komunikasi Arab kelas X dan kepala sekolah SMA Aisyiyah Boarding School Bandung. Dalam pengumpulan data peneliti menggunakan beberapa metode penelitian, yaitu wawancara, observasi, dan angket kelas. Tahap selanjutnya adalah tahap analisis data yang dilakukan dengan metode analisis data deskriptif (Descriptive Analysis), ${ }^{6}$ yakni analisa yang memberikan gambaran tentang hal-hal yang diteliti, dilaksanakan secara interaktif dan berlangsung secara terus menerus sampai tuntas, sehingga datanya sudah jenuh.

Sedangkan uji keabsahan data dalam penelitian ini menggunakan kredibilitas yang dilakukan dengan teknik triangulasi sumber dan metode sebagai langkah pengecekan data dari berbagai sumber, teknik dan waktu penelitian. Hal ini dilakukan guna menghasilkan data dan hasil penelitian yang kredibel tentang pembelajaran komunikasi dalam Pembelajaran Bahasa Arab Di SMA Aisyiyah Boarding School Bandung.

${ }^{6}$ Prof Dr Sugiyono, Metode Penelitian Kuantitatif, Kualitatif Dan R \& D, Alfabeta (Bandung, 
TSAQOFIYA: Jurnal Pendidikan Bahasa dan Sastra, 3 (2), 2021

\section{PEMBAHASAN}

Hasil penelitian yang diperoleh mengenai kegiatan pembelajaran komunikasi Arab yaitu pembahasan dan deskripsimengenai (1) hasil wawancara yang peneliti lakukan untuk mengetahui perencanaan, proses dan evaluasi pembelajarann komunikasi Arab. (2) hasil observasi yang dilakukan peneliti untuk melihat kegiatan guru dan siswa dalam pelaksanakan pembelajaran komunikasi Arab di kelas, dan (3) hasil kuesioner yang peneliti bagikan kepada seluruh siswa kelas X IPS 4 untuk mengetahui kendala apa saja yang dirasakan sehingga menyebabkan kesulitan belajar siswa dalam pembelajaran komunikasi Arab.

Adapun hasil penelitian tentang bagaimana perencanaan, proses, evaluasi, dan kendala pembelajaran komunikasi Arab di kelas X IPS 4 SMA Aisyiyah Boarding School Bandung, yaitu:

Data Hasil Wawancara: Wawancara dilakukan dengan guru mata pelajaran bahasa Arab kelas X untuk mengetahui bagaimana perencanaan, proses, dan evaluasi pembelajaran bahasa Arab di SMA Aisyiyah Boarding School Bandung.

\section{Perencanaan Pembelajaran Komunikasi Arab Siswa Kelas X IPS di SMA Aisyiyah Boarding School Bandung}

Berdasarkan latar belakang dan kajian pustaka yang telah peneliti paparkan, penelitian ini memfokuskan pada bagian perencanaan pembelajaran yang telah dikemukakan oleh Ismawati ${ }^{7}$ bahwa Guru harus menyusun perencanaan pengajaran yang efektif yaitu:

a. Guru harus tahu benar tujuan yang hendak dicapai dalam mengajar. Tujuan pengajaran ini harus dirumuskan seoperasional mungkin agar hasil pengajarannya mudah dievaluasi.

b. Guru harus memutuskan dan menetapkan tingkah laku yang akan dimiliki dan diperlihatkan murid setelah berakhirnya satu periode mengajar-belajar.

c. Guru harus menetapkan satu strategi pengajaran, menyangkut penggunaan metode dan media sebagai prasyarat pencapaian tujuan PBM.

d. Guru harus mempersiapkan alat-alat evaluasi untuk mengetahui seberapa jauh tercapainya tujuan.

${ }^{7}$ E. Ismawati, Perencanaan Pengajaran Bahasa (Yogyakarta: Ombak, 2012). 
Berdasarkan hasil data wawancara mengenai perencanaan pembelajaran komunikasi Arab kelas X dengan Guru yang bersangkutan secara umum dan rinci ialah sebagai berikut:

Pertama, guru mencari materi sesuai kebutuhan siswa, kemudian membuat modul sendiri yang terfokus kepada maharah kalam.

guru mencari silabus sendiri yang dijadikan pedoman dalam melaksanakan pembelajaran bahasa Arab di kelas. Kemudian memilih materi yang tidak terlalu sulit untuk diajarkan, tanpa melupakan tujuan pembelajaran bahasa Arab itu sendiri.

Adapun tujuan pembelajaran bahasa Arab siswa kelas X SMA Aisyiyah Boarding School Bandung ini mengacu pada kurikulum yang berlaku. Yaitu untuk Maharah Takallum dalam Komunikasi Arab diharapkan siswa dapat menghafal dan memahami mufradat atau kosa kata bahasa Arab serta memiliki kepercayaan diri dalam berkomunikasi menggunakan bahasa Arab baik di lingkungan sekolah maupun luar sekolah.

Metode yang digunakan yaitu metode Discovery Learning dan Role Playying. Hal ini telah sesuai dengan yang ditetapkan oleh Departemen Agama dan Departemen Pendidikan Nasional mengenai kebijakan tentang pembelajaran bahasa Arab di SMA dan MA yang dituangkan dalam bentuk kurikulum, yang mana Mata pelajaran bahasa Arab memiliki tujuan sebagai berikut:

1) Mengembangkan kemampuan berkomunikasi dalam bahasa Arab, baik lisan maupun tulis yang mencakup empat kecakapan berbahasa, yakni menyimak (istima), berbicara (kalam), membaca (qira'ah), dan menulis (kitabah).

2) Menumbuhkan kesadaran tentang pentingnya bahasa Arab sebagai salah satu bahasa asing untuk menjadi alat utama belajar, khususnya dalam mengkaji sumber-sumber ajaran Islam.

3) Mengembangkan pemahaman tentang saling keterkaitan antara bahasa dan budaya serta memperluas cakrawala budaya. Dengan demikian, peserta didik diharapkan memiliki wawasan lintas budaya dan melibatkan diri dalam keragaman budaya.

Kedua, merumuskan langkah-langkah pembelajaran yang akan dilaksanakan pada saat proses kegiatan belajar mengajar berlangsung, secara rinci tertuang pada Rencana Pelaksanaan Pembelajaran (RPP) yang telah dibuat oleh Guru yaitu kegiatan pendahuluan yang mana didalamnya mencakup kegiatan guru 
mengucapkan salam, mengabsen siswa, melakukan apersepsi, dan menginformasikan siswa materi yang akan dibahas. Kegiatan inti yang mana didalamnya guru mengajak siswa untuk mengamati, mempertanyakan, mengeksplorasi, mengasosiasi, dan mengkomunikasikan materi yang sedang dibahas.Kegiatan penutup yang didalamnya guru membimbing siswa untuk merumuskan materi dan memberikan tugas/PR.

\section{Proses Pembelajaran Komunikasi Arab Siswa Kelas X di SMA Aisyiyah Boarding School Bandung}

Berdasarkan hasil observasi proses pembelajaran komunikasi Arab di Kelas $\mathrm{X}$, secara rinci peneliti sajikan sebagai berikut;

1) Kegiatan Pendahuluan

Guru hadir dan memulai pembelajaran tepat waktu dilakukan dengan baik, 5 menit sebelum bel berbunyi guru sudah hadir di dalam kelas. Guru memulai pembelajaran dengan mengucapkan salam kemudian menanyakan kabar menggunakan bahasa Arab, mengecek kehadiran siswa, kemudian melakukan apersepsi atau menanyakan pembahasan pertemuan sebelumnya, mengemukakan tujuan pelajaran yang akan dicapai, mengemukakan masalahmasalah pokok yang akan dipelajari, serta menyiapkan siswa secara psikis dan fisik untuk mengikuti proses pembelajaran dilakukan dengan sangat baik. Setelah itu, guru mempersiapkan papan tulis, menuliskan hari, tanggal, serta tema pelajaran yang akan dipelajari.

2) Kegiatan Inti

Guru mempunyai kemampuan berkomunikasi menggunakan bahasa Arab yang baik serta menguasai materi yang disampaikan sehingga siswa mudah memahami materi dan mampu meniru hiwar yang dicontohkan dengan baik. Kemudian guru menjelaskan materi secara rinci namun ringan dan mudah dimengerti, guru memberikan contoh-contoh materi yang diajarkan ke dalam realitas sehari-hari, memberi kesempatan kepada siswa untuk bertanya dan fungsi guru sebagai fasilitator dalam menjawab pertanyaan siswa yang menghadapi kesulitan juga terrealisasi, penggunaan media alat peraga yang digunakan membuat siswa mudah menghafal kosa kata bahasa Arab. Penyampaian materi sesuai dengan yang ada pada bahan ajar yaitu modul komunikasi Arab yang bersumber dari buku Durusul Lughah jilid I, Metode pembelajaran yang digunakan yaitu metode Discovery Learning dan Role Playing. 
3) Kegiatan Penutup

Guru membimbing siswa untuk menyimpulkan materi yang telah dipelajari dengan baik, memberikan tugas/latihan untuk diselesaikan di rumah dan menyampaikan rencana pembelajaran pertemuan selanjutnyadengan jelas, setelah itu guru memberikan motivasi belajar untuk siswa dengan semangat dan baik. Terakhir, guru menutup pembelajaran dengan doa kafaratul majlis dan mengucapkan salam.

\section{Evaluasi Pembelajaran Komunikasi Arab Siswa Kelas X IPS 4 di SMA Aisyiyah Boarding School Bandung}

Berdasarkan hasil wawancara bersama guru yang bersangkutan, tahapan evaluasi yang dilakukan dalam pembelajaran komunikasi Arab yaitu; pertama guru melakukan tes, dengan caramemberikan soal-soal pemahaman dasar bahasa Arab. Ini bertujuan untuk mengetahui sejauh mana siswa mampu berbahasa Arab.

Hal ini disebutkan oleh Matsna dan Mahyudin ${ }^{8}$ bahwa ada jenis-jenis evaluasi dalam pembelajaran bahasa Arab yaitu Evaluasi Penempatan (al-taqwiim altashniifiy) yang mana evaluasi ini bertujuan untuk menetapkan kedudukan seorang siswa di dalam tata urutan pengajaran dan cara mengajar sehingga lebih menguntungkan bagi peserta didik.

Dalam kegiatan sehari-hari, guru melakukan tes/evaluasi komunikasi Arab dengan memberikan teks percakapan bahasa Arab serta mufrodat atau kosa kata baru kepada siswa, kemudian siswa menghafalkannya dan mempraktekkan di depan kelas berpasangan bersma teman sebangkunya.

Kedua, guru mengadakan tes setiap satu bab materi berakhir, evaluasi ini digunakan untuk memantau kemajuan belajar siswa selama pengajaran komunikasi Arab berlangsung dan bertujuan untuk mengetahui sampai dimana penguasaan siswa tentang bahan yang telah diajarkan. Evaluasi bisa berupa tes lisan dan mengumpulkan tugas video percakapan berkelompok.

Ketiga, guru mengadakan tes akhir yaitu Ujian Akhir Semester (UAS). Menurut Matsna dan Mahyudin ${ }^{9}$ ini digunakan untuk pemerolehan siswa pada akhir

${ }^{8}$ Moh Matsna and Erta Mahyudin, “Pengembangan Evaluasi Dan Tes Bahasa Arab," Tangerang Selatan: Alkitabah, 2012.

${ }_{9}^{9}$ Matsna and Mahyudin. 
pengajaran, yang bertujuan untuk mengetahui taraf hasil belajar yang dapat dicapai oleh siswa setelah menyelesaikan program bahan pembelajaran dalam satu kurun waktu tertentu, seperti satu semester. Evaluasi ini berupa test tulis dan mengumpulkan tugas berupa video percakapan berbahasa Arab secara berkelompok.

\section{SIMPULAN}

Pertama, perencanaan pembelajaran disiapkan guru dengan membuat modul pembelajaran komunikasi Arab. Modul tersebut berisi materi-materi khusus maharah kalam yang sudah disesuaikan dengan kebutuhan siswa di kelas. Referensi modul tersebut yaitu dari buku Durusul Lughah Jilid I Gontor dan buku Arabiyya baina yadaik. Setelah itu guru menyiapkan Rancangan Pelaksanaan Pembelajaran (RPP), tujuan pembelajaran komunikasi Arab mengacu pada tujuan sekolah dan tolak ukurnya yaitu siswa mampu berkomunikasi menggunakan bahasa Arab. Indikator keberhasilan dalam pembelajaran komunikasi Arab ini yaitu, siswa diharapkan mampu menghafal mufradat yang telah diberikan serta dapat mengaplikasikannya dalam percakapan sehari-hari dengan penuh rasa percaya diri.

Kedua, proses pembelajaran komunikasi Arab di kelas sudah efektif, terlihat dari ketertiban siswa dalam mengikuti pembelajaran komunikasi Arab. Langkahlangkah pembelajaran pun sudah sesuai dengan teori yang telah disusun oleh guru dalam RPP. Metode yang digunakan untuk pembelajaran komunikasi Arab ini yaitu menggunakan pendekatan Scientific, strategi Inquiry Learning, dan metode pembelajaran dengan cara Tanya Jawab, Penugasan, dan Role Playying. Bahan ajar menggunakan modul yang telah disusun oleh guru dilengkapi buku Durusul Lughah Jilid I dan Arabiya Baina Yadaik. Materi disampaikan perjudul, pemberian mufradat, hiwar, dan pertanyaan-pertanyaan yang sesuai dengan judul materi yang sedang dibahas.

Ketiga, evaluasi pembelajaran komunikasi Arab yang guru lakukan melalui beberapa tahap, evaluasi penempatan dilakukan guru untuk mengelompokkan siswa sesuai kemampuannya sehingga perlakuan yang diberikan dalam pengajaran tidak disamaratakan. Pada evaluasi komunikasi Arab, siswa diberi materi hiwar yang di dalamnya terdapat mufradat-mufradat baru yang beragam, kemudian siswa ditugaskan untuk menghafalkannya, setelah itu siswa diinstruksikan untuk mendemonstrasikan hiwar tersebut di depan kelas secara berpasangan. Evaluasi 
terakhir yaitu guru mengadakan tes lisan setiap satu bab materi dari modul berakhir, evaluasi ini digunakan untuk memantau dan mengukur kemajuan belajar siswa selama pengajaran komunikasi Arab berlangsung, terakhir guru mengadakan Ujian Akhir Semester (UAS).

Keempat, kendala pembelajaran komunikasi Arab yang terjadi dibagi menjadi dua faktor yaitu problematika linguistik dan non linguistik. Problematika linguistik disebabkan karena perbedaan karakteristik internal linguistik bahasa Arab itu sendiri. Problematika non linguistik dibagi menjadi dua faktor, adapun faktor internal meliputi rasa percaya diri, motivasi, kebiasaan belajar, bakat dan minat. Adapun faktor eksternal tidak ada.

\section{DAFTAR PUSTAKA}

Anshor, Ahmad Muhtadi. Pengajaran Bahasa Arab Media Dan Metode-Metodenya. Yogyakarta: Teras, 2009.

Ismawati, E. Perencanaan Pengajaran Bahasa. Yogyakarta: Ombak, 2012.

Kholis, Muhammad Nur, Achmad Jakfar Sodik, Jamaluddin Shiddiq, and Hafidah Hafidah. “Google Form Ka Wasīlah At-Taqyīm FīTa'līm Al-Qirāah Wa Al-Qawā'id Bi Al-Jāmi'ah." LISANIA: Journal of Arabic Education and Literature 4, no. 1 (2020): 80-107.

Matsna, Moh, and Erta Mahyudin. "Pengembangan Evaluasi Dan Tes Bahasa Arab." Tangerang Selatan: Alkitabah, 2012.

Mustofa, Bisri, and M Abdul Hamid. Metode Dan Strategi Pembelajaran Bahasa Arab. UIN-Maliki Press, 2016.

Rosyidi, Abdul Wahab, and Mamlu'atul Ni'mah. Memahami Konsep Dasar Pembelajaran Bahasa Arab. UIN-Maliki Press, 2011.

Sholihah, Siti, and M Nasrullah. “Al-'Alaaqat Bayna Al-Dzaka'I Al-Ma'rifiyy Wa Nataaij Dars Al-Lughat Al-'Arabiyyat Li Thullaab Al-Shaff Al-'Asyir Bi Al-Madrasat Al'Aliyat Al-Islaamjiyyat Al-Hukuumiyyat Al-Tsaaniyyat." Tsaqofiya: Jurnal Pendidikan Bahasa Dan Sastra Arab 1, no. 1 (2019): 36-54.

Sugiyono, Prof Dr. Metode Penelitian Kuantitatif, Kualitatif Dan R \& D. Alfabeta. Bandung, 2010. 